under the new procedures to award about 20 per cent more grants. The beneficiaries will be the 120 or so mathematicians who in the past would have been turned down because of insufficient funds. The losers are the senior scientists whose grants will be trimmed to match one of the two flat rates. (An NSF grant historically pays two-ninths of a researcher's salary, on the assumption that the research is carried out during the summer term. The new grants are not intended to cover summer salary.)

"Fifteen years ago, I didn't worry about those people being turned down because they were not likely to make an important contribution", says Peter Bona, a mathematician at Pennsylvania State University and chairman of the mathematics advisory committee to NSF. "But the people being rejected today are a bit too good to ignore."

The chemistry division, according to its director, Kenneth Hancock, is considering a similar system with three tiers. The first would consist of standard grants, set at a flat rate to eliminate the need for negotiations. The second tier would provide small, starter grants to those new to the field, and the third would bestow large, long-term grants upon eminent senior researchers.

"It's a system in which a lot of people win", says Hancock. "We even found that we could fund at least as many grants as under the current scheme. The trick is that you have to sacrifice a little on the size of the average grant."

A flat rate will present investigators and their institutions with some hard choices, for example to sacrifice a higher salary for a graduate student or to spend money on travel rather than a new computer. Bona says that universities traditionally "make money" on mathematics departments because the scientists require little costly equipment or special facilities and that the new system may induce them to revise their bookkeeping and "to return some of that money" to mathematics.

The experiment, if successful, could be modified for other disciplines; in some ways, it extends efforts already under way to streamline the process. NSF officials have resolved to enforce an existing 15-page limit on grant applications, and the biology directorate has successfully used brief pre-proposals to screen applicants for multimillion-dollar training grants. The entire campaign, says Charles Brownstein, director of the office of planning and assessment, "is driven by a desire to avoid having highly qualified people become clerks".

The mathematics trial is scheduled to run for at least the 1993 fiscal year, which begins on 1 October, and possibly into 1994. Bona says the advisory committee will "be watching it like a hawk" and is prepared to make changes, or to jettison it, if there are signs that the new system is funding research of lower quality.

\title{
Canadian research council found guilty of job bias
}

Quebec. The National Research Council (NRC) of Canada, the country's largest research and development organization, has been found guilty of racial discrimination against an Indian-born physicist and ordered to review its human rights policy towards its employees. The ruling was made by the Canadian Human Rights Tribunal in

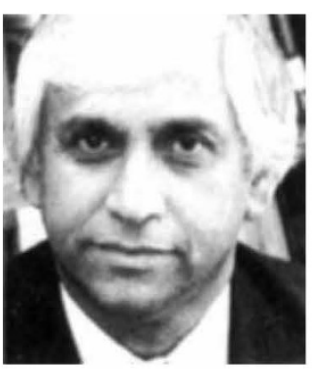

Chander Grover a strongly worded decision issued on 21 August that recommended prosecution of several NRC employees for violating the country's Human Rights Act.

NRC says that it is "surprised and shocked" by what is believed to be the first such investigation involving the council. Yet it seems unlikely to be the last. The complainant, Chander P. Grover, who arrived in Canada in 1978, claims that he was harassed by NRC even after the tribunal published its decision. Grover has made two further complaints that are being investigated by the Canadian Human Rights Commission, and has submitted two related grievances to the Public Service Staff Relations Board. A similar complaint — on the same grounds and against the same group of people at NRC - has also been submitted to the Human Rights Commission office by a former colleague of Grover's, Chinese physicist Tony Liu. A ruling is expected within the next few months.

The Canadian Human Rights Commission was established by the federal government in 1977 to investigate and resolve complaints of discrimination on such grounds as race, origin, religion, sex, age and disability. By last year it had more than 2,500 cases pending, 10 per cent claiming discrimination because of race and 12 per cent because of national origin.

Grover alleged that he was denied managerial, promotional and research opportunities in a series of incidents between September 1986 and August 1987. He works in the physics division at the NRC in Ottawa, and claimed discrimination on the basis of race, colour and national origin. In 1987 there were no visibly minority scientists within the senior management of the physics division.

After receiving degrees from the universities of Delhi and Paris VI and acquiring extensive research experience, Grover joined NRC in 1981 as an associate research professor within the physics division, and, ac- cording to a previous director, "quickly became our leading expert in modern optics... his research work has brought him national as well as international recognition...”.

In 1985 he became acting director of a new optics institute within the NRC that later became an independent National Optics Institute. He was appointed interim scientific director of the new institute, located in Quebec City, but in January 1987 turned down an offer to take the job on a permanent basis.

Grover's superiors then attacked his reputation, reduced his research activities, dismantled his research team, withheld his funding and left his future with the NRC uncertain, according to the tribunal. At one point, he was told he was being dismissed for disciplinary reasons, but the action was reversed the day before a staff hearing into his complaint.

In its 94-page decision, the tribunal found NRC's actions "flagrant and calculated to humiliate and demean the Complainant" and the cause of health problems for Grover and his family. NRC's own human rights adviser played a role in the debacle, the tribunal said: "After receiving in confidence Dr Grover's entire story about the complaints of his treatment...[she] then turns about and becomes the representative of the National Research Council throughout these complaints and the subsequent hearing". From the beginning of Grover's complaints to the last day of the hearing, the tribunal found, "NRC endeavoured to apply pressure on witnesses as well as control and prevent the introduction of some of the evidence".

NRC's treatment of Grover restricted his international activities and harmed his career. A last-minute cancellation of a trip to present a paper at a meeting in Boston of the Optical Society of America, to which he had recently been elected a fellow, "was professionally a great embarrassment for $\mathrm{Dr}$ Grover".

The tribunal called for a formal written apology to Grover from NRC's president within 15 days, to be published in an NRC publication, and an apology from the NRC president to the optical society. It ordered NRC to appoint Grover to at least a position of section head, to pay him lost wages, to cease its discrimination against him and to pay his legal fees and $\$ 5,000$ for emotional distress (the maximum allowed), including interest.

NRC is considering an appeal but has otherwise refrained from comment. It has 30 days to file an appeal, which would be heard by a division of Justice Department.

David Spurgeon 